\title{
REVIEW
}

\section{Patient Characteristics Associated with Adverse Drug Events in Hospital: An Overview of Reviews}

\author{
Silvija Mihajlovic, Jeremie Gauthier, and Erika MacDonald
}

\begin{abstract}
Background: Adverse drug events (ADEs) occurring in hospital inpatients can have serious implications. The ability to identify and prioritize patients at higher risk of ADEs could help pharmacists to optimize their impact as members of the patient care team.

Objective: To identify risk factors, patient characteristics, and medications associated with a higher likelihood of ADEs in adult inpatients through an overview of reviews on this topic.

Data Sources: Systematic reviews and narrative reviews or guidelines identified through a search of MEDLINE and the Cochrane Database of Systematic Reviews (limited to articles published from 1995 to June 4, 2015), as well as a grey literature search.

Study Selection and Data Extraction: For inclusion in this overview, a review had to discuss patient characteristics or risk factors associated with ADEs, medications associated with ADEs, or drug-drug interactions associated with ADEs, in adult inpatients. Articles retrieved by the literature search were screened for eligibility by a single reviewer.

Data Synthesis: Eleven articles were deemed eligible for inclusion in this overview: 4 systematic reviews and 7 narrative reviews or guidelines. Their results were described narratively. Older age and polypharmacy were the most frequently cited risk factors associated with ADEs in hospital inpatients. Renal impairment, female sex, and decline in cognition were also frequently reported as being associated with ADEs. Medication classes reported to be associated with ADEs during the hospital stay included anticoagulants, anti-infectives/antibiotics, antidiabetic agents, analgesics (including opioids and nonsteroidal anti-inflammatory drugs), and cardiovascular drugs (including antihypertensive agents, diuretics, and digoxin). Two publications reported on preventable ADEs in hospital inpatients; the medications associated with preventable ADEs were consistent with those reported above.
\end{abstract}

Conclusions: The risk factors, patient characteristics, and medication classes highlighted in this overview may help clinicians to prioritize patient populations who may be at higher risk of ADEs.

Keywords: adverse drug event, systematic review, review, risk factors, medications, hospital

Can J Hosp Pharm. 2016;69(4):294-300

\section{RÉSUMÉ}

Contexte : Les événements indésirables liés aux médicaments (EIM) touchant les patients hospitalisés peuvent avoir de graves conséquences. La capacité d'identifier les patients qui présentent un haut risque d'EIM et de les prioriser pourrait aider les pharmaciens à optimiser l'influence qu'ils exercent comme membres de l'équipe de soins aux patients.

Objectif : Identifier les facteurs de risque, les caractéristiques des patients ou les médicaments associés à un potentiel plus élevé d'EIM chez les patients adultes hospitalisés à l'aide d'une synthèse des comptes rendus sur le sujet.

Sources des données : Des analyses systématiques et des revues narratives ou des lignes directrices trouvées à l'aide d'une recherche dans MEDLINE et la Cochrane Database of Systematic Reviews (se limitant aux articles publiés entre 1995 et le 4 juin 2015) et d'une recherche dans la littérature grise.

Sélection des études et extraction des données : Afin d'être admissible à la présente synthèse, un compte rendu devait aborder les caractéristiques des patients ou les facteurs de risque associés aux EIM, les médicaments associés aux EIM ou les interactions médicament-médicament associées aux EIM chez le patient adulte hospitalisé. L'admissibilité des articles trouvés grâce à la recherche documentaire n’a été évaluée que par une seule personne.

Synthèse des données : Les résultats des comptes rendus retenus ont été décrits de manière narrative. Onze articles ont été admis dans la présente synthèse : quatre analyses systématiques et sept revues narratives ou lignes directrices. Lâge avancé et la polypharmacie représentaient les facteurs de risque associés aux EIM les plus souvent mentionnés chez le patient adulte hospitalisé. Linsuffisance rénale, le sexe féminin et le déclin cognitif étaient eux aussi fréquemment indiqués comme étant des facteurs liés aux EIM. Parmi les classes de médicaments signalées comme étant associées aux EIM pendant le séjour à l'hôpital, on comptait : les anticoagulants, les anti-infectieux et les antibiotiques, les antidiabétiques, les analgésiques (notamment les opioïdes et les anti-inflammatoires non stéroïdiens) et les agents cardiovasculaires (notamment les antihypertenseurs, les diurétiques et la digoxine). Deux publications abordaient les EIM évitables chez le patient hospitalisé; les médicaments associés aux EIM faisaient partie de ceux mentionnés ci-dessus.

Conclusion : Connaître les facteurs de risque, les caractéristiques des patients et les classes de médicaments mis en évidence dans la présente synthèse peut aider les cliniciens à accorder la priorité aux populations de patients qui pourraient présenter un plus grand risque d'EIM.

Mots clés : événement indésirable lié à un médicament, analyse systématique, revue, facteurs de risque, médicaments, hôpital 


\section{INTRODUCTION}

The occurrence of adverse drug events (ADEs) in hospital 1 inpatients can have serious implications, including disability, death, prolonged hospital stay, and increased costs. ${ }^{1}$

The Canadian Adverse Events Study, published in 2004, found that $37 \%$ of adverse events occurring in Canadian hospitals were preventable. ${ }^{2}$ Twenty-four percent of these preventable adverse events were associated with drug or fluid administration. $^{2}$

An adverse event has been defined by the World Health Organization $^{3}$ as "[a]ny untoward medical occurrence that may present during treatment with a pharmaceutical product but which does not necessarily have a causal relationship with this treatment"; such events can be characterized as either preventable or nonpreventable. An adverse drug reaction (ADR) is a type of ADE that involves "suspicion of a causal relationship between the drug and the occurrence" and that "occurs at doses normally used in humans for the prophylaxis, diagnosis, or therapy of disease, or for the modification of physiological function". ${ }^{3}$

The ability to identify and prioritize patients at higher risk of ADEs could help pharmacists to maximize their impact as members of the patient care team. The objective of this overview of reviews was to identify risk factors, patient characteristics, and medications associated with a higher likelihood of ADEs in adult inpatients.

\section{METHODS}

An overview of reviews was thought to be the most appropriate method to meet our objective, because we were interested in summarizing the evidence for a very broad research question. MEDLINE and the Cochrane library were searched, in collaboration with an information specialist, up to June 4, 2015, using keywords such as "adverse drug event", "hospital", and "review". The full search strategy is available in Appendix 1 (www.cjhp-

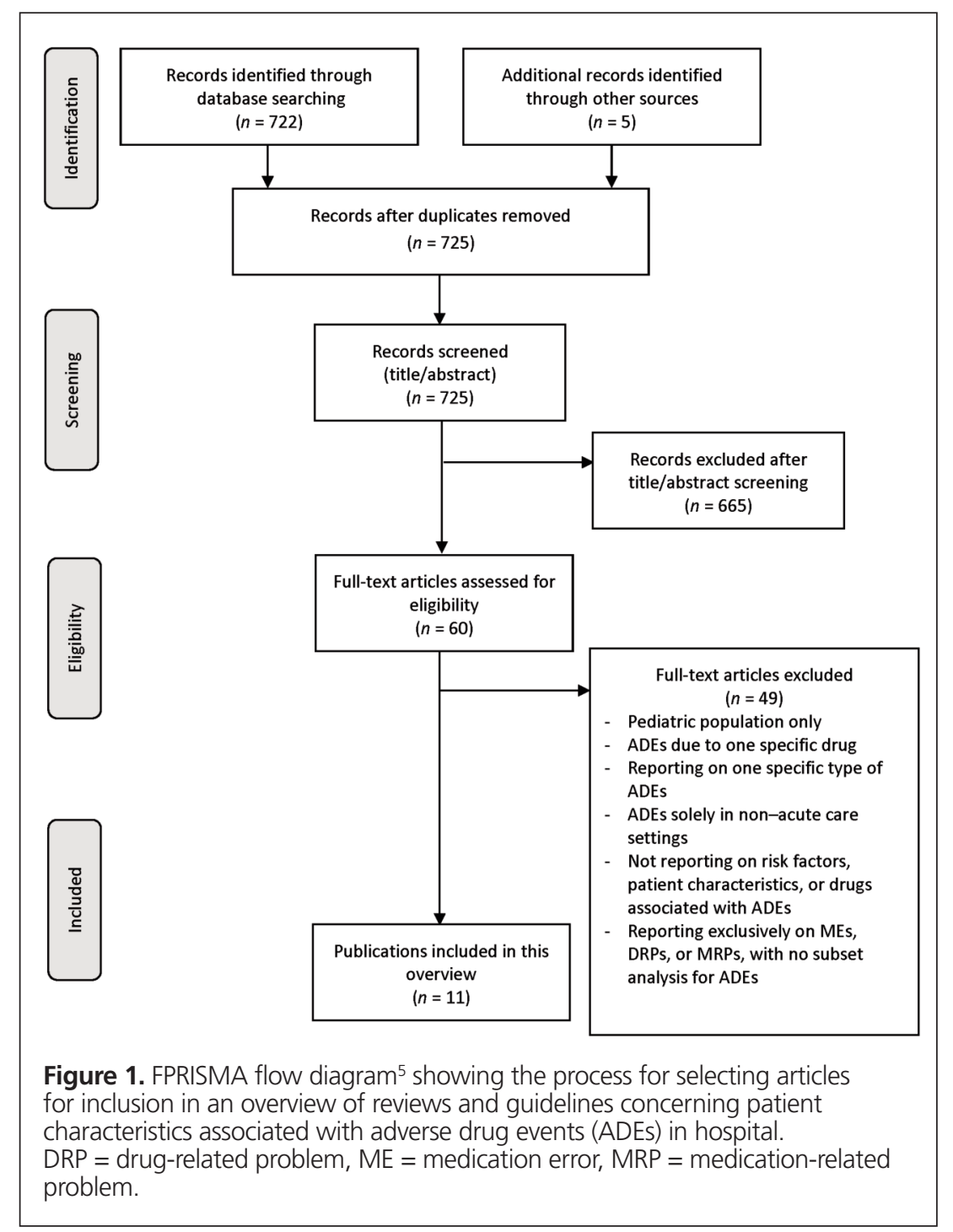


online.ca/index.php/cjhp/issue/view/116/showToc). Additionally, a grey literature search was performed using the Grey Matters guide of the Canadian Agency for Drugs and Technologies in Health. ${ }^{4}$ Publication type was limited to narrative reviews, systematic reviews, and guidelines published in 1995 or later.

For the purposes of this overview, a systematic review was defined as a review that used systematic methods to identify, select, and synthesize studies. Eligible reviews had to report on at least one of the following: patient characteristics or risk factors associated with ADEs, medications associated with ADEs, or drug-drug interactions associated with ADEs. Only reviews reporting on ADEs occurring in hospital inpatients and those that combined inpatient and outpatient data were included. Reviews reporting exclusively on ADEs leading to hospital admission and those occurring exclusively in outpatients were excluded. Publications were also excluded if they reported on pediatric patients only or assessed only one specific drug, condition, or type of ADE. Publications reporting on drug-related problems, medication-related problems, or medication errors were selected only if a separate analysis specific to ADEs was performed.

The titles and abstracts of all articles retrieved through the literature search were screened for eligibility by a single reviewer
(S.M.). The full texts of all potentially relevant articles were retrieved and screened by the same reviewer to confirm eligibility.

\section{RESULTS}

The electronic database search retrieved 722 articles, and an additional 5 articles were identified through the grey literature search. After removal of duplicates and screening of titles and abstracts, 60 full-text articles were retrieved for review (Figure 1). After full-text review, 11 articles were deemed eligible for inclusion. ${ }^{6-16}$

The characteristics of the included reviews are summarized in Table 1. Of the included publications, 4 were systematic reviews ${ }^{6,9,11,15}$ and 7 were narrative reviews or guidelines. ${ }^{7,8,10,12-14,16}$ Seven reviews reported on ADEs occurring during the hospital stay only, ${ }^{7-9,11-13,16} 2$ reported both inpatient and outpatient data, ${ }^{10,14}$ and 2 reported on ADRs leading to or occurring during admission. ${ }^{6,15}$

Two of the 11 publications focused on ADEs or ADRs in elderly patients, ${ }^{6,7} 1$ study commented on drug-drug interactions often associated with ADEs, ${ }^{10}$ and 2 investigated preventable ADEs. ${ }^{11,14}$

\section{Table 1. Characteristics of Included Reviews}

\begin{tabular}{|c|c|c|c|}
\hline Reference & Study Design & Population & Objectives \\
\hline Wiffen et al. $(2002)^{15}$ & Systematic review & Patients of all ages & $\begin{array}{l}\text { To (1) estimate the incidence of ADRs in patients resulting in } \\
\text { hospitalization or occurring in hospital, ( } 2 \text { ) estimate the burden of } \\
\text { ADRs for the United Kingdom, (3) identify risk factors for ADRs, } \\
\text { and (4) identify ways by which they can be reduced }\end{array}$ \\
\hline $\begin{array}{l}\text { Kanjanarat et al. } \\
(2003)^{11}\end{array}$ & Systematic review & $\begin{array}{l}\text { Hospitalized patients } \\
\text { of all ages }\end{array}$ & $\begin{array}{l}\text { (1) To describe the drug classes and types of errors and outcomes } \\
\text { most frequently associated with preventable ADEs in hospitalized } \\
\text { patients and (2) to determine high-risk areas to focus on for } \\
\text { "quality improvement" }\end{array}$ \\
\hline $\begin{array}{l}\text { Krähenbühl-Melcher } \\
\text { et al. (2007)9 }\end{array}$ & Systematic review & $\begin{array}{l}\text { Hospitalized patients } \\
\text { (age not specified) }\end{array}$ & $\begin{array}{l}\text { To describe the frequency of and risk factors for medication errors } \\
\text { and ADEs in hospitalized patients and how they can be avoided }\end{array}$ \\
\hline Alhawassi et al. (2014) & Systematic review & $\begin{array}{l}\text { Elderly patients in the } \\
\text { acute care setting } \\
\text { ( } \geq 65 \text { years) }\end{array}$ & $\begin{array}{l}\text { To estimate the prevalence of and risk factors for ADRs in the } \\
\text { elderly, either leading to hospital admission or occurring during } \\
\text { admission }\end{array}$ \\
\hline Davies et al. $(2007)^{8}$ & Narrative review & Not defined & $\begin{array}{l}\text { To determine the incidence, causative drugs, and prevention } \\
\text { strategies for ADRs occurring in hospital }\end{array}$ \\
\hline$\overline{\text { Magro et al. }(2012)^{10}}$ & Narrative review & $\begin{array}{l}\text { Inpatients and } \\
\text { outpatients (age not } \\
\text { specified) }\end{array}$ & $\begin{array}{l}\text { To report on the incidence, characteristics of, and prevention } \\
\text { strategies for ADRs caused by drug-drug interactions in inpatients } \\
\text { and outpatients }\end{array}$ \\
\hline Petrovic et al. (2012) ${ }^{7}$ & Narrative review & $\begin{array}{l}\text { Older adults (age } \\
\text { range not specified) }\end{array}$ & $\begin{array}{l}\text { To summarize strategies for improving recognition and prevention } \\
\text { of ADRs }\end{array}$ \\
\hline $\begin{array}{l}\text { Weiss and Elixhauser } \\
(2013)^{12}\end{array}$ & Statistical brief & $\begin{array}{l}\text { Patients admitted to } \\
\text { hospital in } 2011 \text { in } \\
32 \text { states in the United } \\
\text { States }\end{array}$ & $\begin{array}{l}\text { To report statistics regarding the } 4 \text { most common causes of ADEs } \\
\text { occurring during hospitalization of patients in } 2011 \text { from } 32 \text { US } \\
\text { states participating in the Healthcare Cost and Utilization Project }\end{array}$ \\
\hline Weiss et al. $(2013)^{13}$ & Statistical brief & $\begin{array}{l}\text { Patients admitted to } \\
\text { hospital in } 2011 \text { in } \\
32 \text { states in the United } \\
\text { States }\end{array}$ & $\begin{array}{l}\text { To report statistics regarding the origin of ADEs (either } \\
\text { originating in hospital or present on admission) in patients } \\
\text { hospitalized in } 2011 \text { from } 32 \text { US states participating in the } \\
\text { Healthcare Cost and Utilization Project }\end{array}$ \\
\hline $\begin{array}{l}\text { US Department of } \\
\text { Health and Human } \\
\text { Services }(2014)^{14}\end{array}$ & Report & $\begin{array}{l}\text { Inpatient and } \\
\text { outpatient data from } \\
\text { the United States }\end{array}$ & $\begin{array}{l}\text { To identify the most common preventable ADEs and, in } \\
\text { conjunction with federal health agencies, to develop a US } \\
\text { national action plan to prevent these specific ADEs }\end{array}$ \\
\hline $\begin{array}{l}\text { Zhu and Weingart } \\
(2015)^{16}\end{array}$ & $\begin{array}{l}\text { Clinical guidelines and } \\
\text { recommendations }\end{array}$ & $\begin{array}{l}\text { Hospitalized patients } \\
\text { of all ages }\end{array}$ & $\begin{array}{l}\text { To discuss strategies for preventing ADEs caused by medication } \\
\text { errors in hospitalized patients }\end{array}$ \\
\hline
\end{tabular}

$\overline{\mathrm{ADE}}=$ adverse drug event, $\mathrm{ADR}=$ adverse drug reaction . 
This single copy is for your personal, non-commercial use only.

For permission to reprint multiple copies or to order presentation-ready copies for distribution, contact CJHP at cjhpedit@cshp.ca

Table 2 (part 1 of 3). Summary of Risk Factors for Adverse Drug Events Identified in Included Reviews

\begin{tabular}{|c|c|c|}
\hline Reference & $\begin{array}{l}\text { Results, as No. of Included Studies (Systematic Reviews Only) } \\
\text { and ADE Risk Factors Identified }\end{array}$ & Comments \\
\hline Wiffen et al. (2002) & $\begin{array}{l}9 \text { studies } \\
\text { - Elderly patients (especially > } 70 \text { years) } \\
\text { - Increasing number of medications } \\
\text { - } \geq 5 \text { diagnoses } \\
\text { - Admission with gastrointestinal bleeding or hematuria } \\
\text { - Low cognition } \\
\text { - Female sex } \\
\text { - Medications more likely to cause ADRs (making up 60\%-70\% of all ADRs } \\
\text { either leading to admission or occurring in hospital): } \\
\text { - Antibiotics (one study reported } 9 \% \text { of preventable ADRs were due to } \\
\text { antibiotics, while } 30 \% \text { of nonpreventable ADRs were as a result of } \\
\text { antibiotic use) } \\
\text { - Anticoagulants } \\
\text { - Primarily warfarin, but some studies cited heparin } \\
\text { - One study reported that } 40 \% \text { of anticoagulation-related ADRs } \\
\text { - were preventable } \\
\text { - Digoxin and digitalis } \\
\text { - Hypotics } \\
\text { - NSAIDs }\end{array}$ & $\begin{array}{l}\text { Limited to prospective cohort } \\
\text { studies or case-control studies } \\
\text { Quality of included studies } \\
\text { was not assessed }\end{array}$ \\
\hline $\begin{array}{l}\text { Kanjanarat et al. } \\
(2003)^{11}\end{array}$ & $\begin{array}{l}10 \text { studies } \\
\text { Drugs most frequently associated with preventable ADEs: } \\
\text { - Cardiovascular drugs (17.9\% of all preventable ADEs, range 4.3\%-28.1\%) } \\
\text { - Most frequently reported: antihypertensives, B-blockers, ACE inhibitors, } \\
\text { and nitrates } \\
\text { - Psychoactive and other CNS drugs (15.3\%, range 2.6\%-20.5\%) } \\
\text { - Reported as sedatives, hypnotics, antidepressants, antipsychotic agents, } \\
\text { benzodiazepines, and their combinations } \\
\text { - Analgesics (12.8\%, range } 6.7 \%-28.6 \%) \\
\text { - Most frequently reported: opioids } \\
\text { - NSAIDs rarely or not mentioned in these studies } \\
\text { - Anticoagulants (9.8\%, range } 4.3 \%-20.0 \%) \\
\text { - Anti-infectives (9.6\%, range 3.3\%-42.1\%) } \\
\text { - Reported as penicillins, cephalosporins }\end{array}$ & $\begin{array}{l}\text { Unpublished reports were } \\
\text { not included } \\
\text { Quality of included studies } \\
\text { was not assessed } \\
\text { Variable definitions of } \\
\text { "preventability" across } \\
\text { included studies }\end{array}$ \\
\hline $\begin{array}{l}\text { Krähenbühl-Melcher } \\
\text { et al. (2007)9 }\end{array}$ & $\begin{array}{l}35 \text { studies } \\
\text { Risk factors for ADEs: } \\
\text { - Polypharmacy (reported in } 6 \text { of the } 11 \text { studies that reported on } \\
\text { ADR risk factors) } \\
\text { - Female sex (reported in } 4 \text { studies) } \\
\text { - Use of drugs with narrow therapeutic range (reported in } 3 \text { studies) } \\
\text { - Age > } 65 \text { years (reported in } 3 \text { studies) } \\
\text { - Renal elimination of drugs (reported in } 2 \text { studies) } \\
\text { - Use of oral anticoagulants (reported in } 2 \text { studies) } \\
\text { - Use of diuretics (reported in } 2 \text { studies) }\end{array}$ & $\begin{array}{l}\text { Inclusion criteria limited to } \\
\text { reports in English, French, } \\
\text { or German } \\
\text { A majority of patients were in } \\
\text { internal medicine, surgery, } \\
\text { or geriatric wards or in ICÚs } \\
\text { Quality of included studies } \\
\text { was not assessed } \\
\text { Patient characteristics of } \\
\text { included studies were not } \\
\text { provided }\end{array}$ \\
\hline $\begin{array}{l}\text { Alhawassi et al. } \\
(2014)^{6}\end{array}$ & $\begin{array}{l}\text { 14 studies } \\
\text { Risk factors for ADRs: } \\
\text { A. Patient-related risk factors: age, * female sex, rural residential location, } \\
\text { socioeconomic status } \\
\text { B. Disease-related risk factors: comorbid burden, }{ }^{*} \text { conditions such as } \\
\text { cardiovascular disease, diabetes mellitus, cancer, depression, impaired renal } \\
\text { function, dementia, hyperlipidemia, elevated white blood cells, } \\
\text { and liver disease } \\
\text { C. Medication-related factors: number of medications (number not defined), * } \\
\text { drug-drug interactions, cardiovascular medications (including } \\
\text { antihypertensives, diuretics, and ACE inhibitors), antithrombotic/ } \\
\text { anticoagulant medications, antibacterials, NSAIDs, antidiabetic medications, } \\
\text { psycholeptics } \\
\text { D. Other factors: history of falls, limitations in activities of daily living }\end{array}$ & $\begin{array}{l}\text { Limited to observational studies } \\
\text { Considerable heterogeneity } \\
\text { was found among the } \\
14 \text { studies included in the } \\
\text { review } \\
\text { Variable quality of included } \\
\text { studies } \\
\text { Unpublished literature was } \\
\text { not included }\end{array}$ \\
\hline
\end{tabular}


Table 2 (part 2 of 3). Summary of Risk Factors for Adverse Drug Events Identified in Included Reviews

\begin{tabular}{|c|c|c|}
\hline Reference & $\begin{array}{c}\text { Results, as No. of Included Studies (Systematic Reviews Only) } \\
\text { and ADE Risk Factors Identified }\end{array}$ & Comments \\
\hline Davies et al. $(2007)^{8}$ & $\begin{array}{l}\text { - Older age (may be an independent risk factor but difficult to separate from } \\
\text { confounding factors) } \\
\text { - Polypharmacy (number of drugs not defined) } \\
\text { - Impaired renal function } \\
\text { - Female sex } \\
\text { - Clinical setting } \\
\text { - Majority of ADR studies have been done in general medical units } \\
\text { - When adjusted for number of medications ordered, the rate of preventable } \\
\text { and potential ADEs is similar in ICUs and non-ICU settings } \\
\text { - Medical ICUs have a higher rate of ADEs than surgical ICUs } \\
\text { - Drugs associated with ADRs during hospitalization: antibiotics, diuretics, } \\
\text { cardiac glycosides, and antihyperglycemics } \\
\text { - Drugs implicated in ADRs in surgical patients: NSAIDs and opiates } \\
\text { - Drugs implicated in ADRs in elderly hospitalized patients: diuretics }\end{array}$ & - \\
\hline Magro et al. $(2012)^{10}$ & $\begin{array}{l}\text { Risk factors for adverse drug interactions: } \\
\text { - Polypharmacy (number not defined) } \\
\text { - Increase in number of prescribing physicians } \\
\text { - Associated with polypharmacy and an increase in number of } \\
\text { pharmacies visited } \\
\text { - Patients who self-medicate without discussion with a physician } \\
\text { - Age } \\
\text { - Drugs with narrow therapeutic range (including warfarin, cyclosporine, } \\
\text { - Glozapine, lithium, digoxin, phenytoin, and theophylline) } \\
\text { - Genetic polymorphisms }\end{array}$ & $\begin{array}{l}\text { Inpatient and outpatient data } \\
\text { were not separated } \\
\text { Reported only on ADEs } \\
\text { resulting from drug-drug } \\
\text { interactions }\end{array}$ \\
\hline Petrovic et al. $(2012)^{7}$ & $\begin{array}{l}\text { - Renal or hepatic impairment } \\
\text { - Age } \\
\text { - No. of medications patient is receiving } \\
\text { - Polypharmacy (> } 5 \text { medications) } \\
\text { - Nonadherence } \\
\text { - Living alone } \\
\text { - Receiving drugs from different prescribers } \\
\text { - Cognitive problems } \\
\text { - Poor knowledge of drugs prescribed } \\
\text { - Inappropriate prescribing } \\
\text { - Previous occurrence of ADR } \\
\text { - GerontoNet ADR Risk Score } \\
\text { - Validated risk score calculator for identifying patients who are at } \\
\text { increased risk of an ADR in a population of in-hospital older adults } \\
\text { - Score is determined as follows: } \geq 4 \text { comorbid conditions (1 point), } \\
\text { congestive heart failure (1 point), liver disease defined as liver function } \\
\text { tests > } 2 \times \text { upper limit of normal (1 point), no. of drugs (<5 drugs, } \\
0 \text { points; } 5 \text {-7 drugs, } 1 \text { point; } \geq 8 \text { drugs, } 4 \text { points), previous ADR } \\
\text { (2 points), renal failure defined as eGFR < } 60 \text { mL/min ( } 1 \text { point) }\end{array}$ & $\begin{array}{l}\text { Use of GerontoNet ADR Risk } \\
\text { Score not validated in a North } \\
\text { American population }\end{array}$ \\
\hline $\begin{array}{l}\text { Weiss and Elixhauser } \\
(2013)^{12}\end{array}$ & $\begin{array}{l}\text { - Medication classes specifically identified as causes of ADEs occurring } \\
\text { during hospitalization: } \\
\text { - Steroids } \\
\text { - Antibiotics } \\
\text { - Opiates and narcotics } \\
\text { - Anticoagulants } \\
\text { - ADEs involving opiates and narcotics were higher in females, whereas } \\
\text { ADEs involving anticoagulants were lower in females } \\
\text { - ADE rates for adults in the } 45-64 \text { and } \geq 65 \text { age groups were } 63 \%-947 \% \\
\text { higher than ADE rates for adults for the } 18-44 \text { age group } \\
\end{array}$ & $\begin{array}{l}\text { Reported on ADEs occurring } \\
\text { within a 1-year span in the } \\
\text { United States } \\
\text { Conclusions based on ADEs } \\
\text { occurring in patients of all ages } \\
\text { (including pediatric patients) }\end{array}$ \\
\hline Weiss et al. $(2013)^{13}$ & $\begin{array}{l}\text { - ADEs were } 3 \text { times more likely to be present on admission rather than } \\
\text { originating in hospital } \\
\text { - Most frequent general causes of ADEs occurring in hospital: } \\
\text { - Antibiotics and infectives ( } 28 \% \text { of all ADEs) } \\
\text { - Nonspecific ADE causes (16.6\%) } \\
\text { - Hormones (including steroids, insulin, and hypoglycemic agents) (16.1\%) } \\
\text { - Analgesics (including opiates/narcotics and NSAIDs) (12.6\%) } \\
\text { - CNS depressants and anesthetics were more likely to be the cause of ADEs } \\
\text { originating while in hospital rather than being the cause of admission } \\
\text { - Antibiotics were equally likely to be the cause of ADEs presenting on admission } \\
\text { and ADEs occurring during hospital stay }\end{array}$ & $\begin{array}{l}\text { Reported on ADEs occurring } \\
\text { within a 1-year span in the } \\
\text { United States } \\
\text { Patient characteristics not } \\
\text { provided }\end{array}$ \\
\hline
\end{tabular}


This single copy is for your personal, non-commercial use only.

For permission to reprint multiple copies or to order presentation-ready copies for distribution, contact CJHP at cjhpedit@cshp.ca

\section{Table 2 (part 3 of 3). Summary of Risk Factors for Adverse Drug Events Identified in Included Reviews}

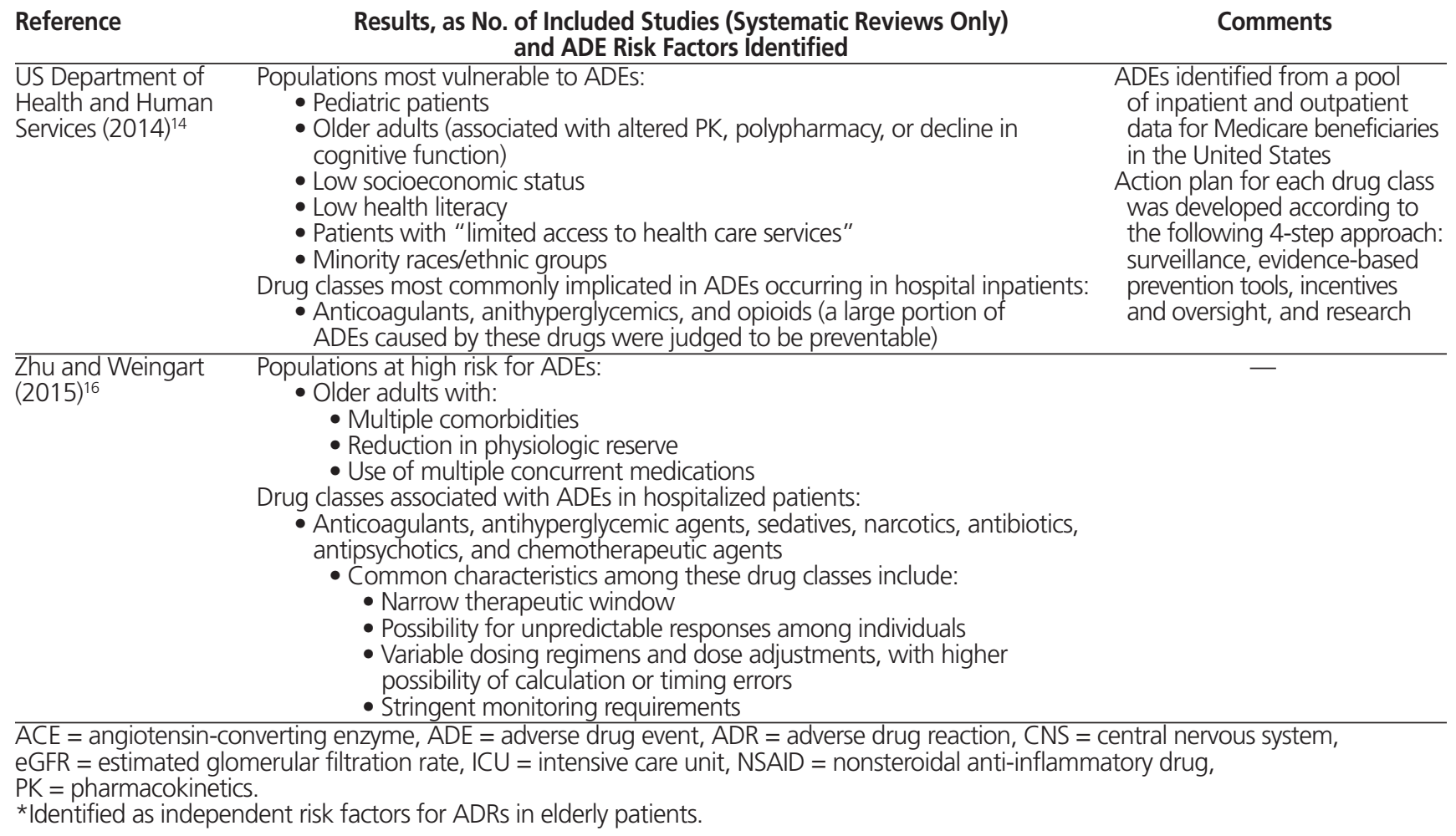

Several risk factors were frequently cited as being associated with ADEs in adult inpatients, as summarized in Table 2. ${ }^{6-16} \mathrm{Of}$ note, older age $\mathrm{e}^{6-10,12,14-16}$ and polypharmacy ${ }^{6-10,14-16}$ were the most frequently cited risk factors among the included reviews. However, the included reviews did not consistently and clearly define these risk factors. For example, 2 publications defined "elderly" as age over 65 and age over 70, respectively. ${ }^{9,15}$ In one publication that identified polypharmacy as a risk factor for ADEs, this term was defined as 5 or more medications. ${ }^{7}$ Renal impairment, ${ }^{6-8}$ female sex, ${ }^{6,8,9,15}$ and decline in cognition ${ }^{6,7,15}$ were also frequently reported as being associated with ADEs. Drugdrug interactions were cited as risk factors for ADEs in 2 reviews, ${ }^{6,10}$ and one of these ${ }^{10}$ reported specifically on ADRs caused by drug-drug interactions; the risk factors for adverse drug interactions were consistent with those reported in other reviews, and included polypharmacy and older age. ${ }^{10}$

Medication classes reported to be associated with ADEs during the hospital stay included anticoagulants, ${ }^{6,9,11,12,14-16}$ antiinfectives/antibiotics, ${ }^{6,8,11-13,15,16}$ antihyperglycemic agents ${ }^{6,8,13-16}$ analgesics (including opioids/narcotics ${ }^{8,11-14,16}$ and nonsteroidal anti-inflammatory drugs $\left.\mathrm{s}^{6,8,13,15}\right)$, and cardiovascular drugs (including antihypertensive agents, diuretics, and digoxin). ${ }^{6,8,9,11,15}$ Two publications reported on preventable ADEs in hospital inpatients; the medication classes were consistent with those reported above (including anticoagulants, anti-infectives, antihyperglycemic agents, cardiovascular drugs, and opioids). ${ }^{11,14}$

\section{DISCUSSION}

Several risk factors, patient characteristics, and medications associated with ADEs were identified in this overview of systematic reviews, narrative reviews, and guidelines.

Not surprisingly, older age and polypharmacy were consistently associated with ADEs. Age-related pharmacodynamics and pharmacokinetic changes were cited as factors contributing to the frequent association of older age with ADEs. ${ }^{6-8,15}$ Pharmacists could optimize care by considering patient age in the selection and dosing of medications and by ensuring discontinuation of medications when appropriate. In addition to the lack of clear definitions for polypharmacy and older age among the included reviews, there was also a lack of agreement among the studies as to whether these characteristics were independent risk factors for ADEs. Independent causal associations are difficult to assess, because of the nature of the studies included in the reviews; potential confounding factors such as comorbid conditions, renal and hepatic function, and cognitive function are examples of the many important considerations when assessing older age and polypharmacy as independent risk factors for ADEs. Renal impairment was also frequently cited as being associated with ADEs, and drug-drug interactions were identified as another potential source of ADEs. These factors represent 2 other potential areas of focus for pharmacists, who can take steps to ensure appropriate drug dosing in renal impairment and screening for clinically significant drug-drug interactions. 
Several medication classes were implicated in ADEs. Targeting patients who are taking anticoagulants, cardiovascular drugs, antibiotics, antihyperglycemic agents, and analgesics may be one approach to efficiently allocate clinicians' time and resources; however, the volume of drugs that fall within these classes may prevent this from being a feasible approach. Nevertheless, being cognizant of these drug classes, optimizing doses, ensuring the appropriateness of drug therapy, and ensuring that appropriate monitoring is in place may be ways in which pharmacists can prioritize their services.

This overview had several potential limitations. The selection of articles for inclusion was performed by a single reviewer. Articles were not assessed for overlap of primary studies within the included reviews. Only 2 of the included reviews focused on preventable ADEs; all of the other reviews did not differentiate between preventable and nonpreventable ADEs. If these reviews were to be used for prioritization of pharmacist resources, this is an important consideration, as there may be little benefit in targeting patients at risk of nonpreventable ADEs. Evidence related to the effectiveness of interventions aimed at preventing ADEs in hospital inpatients would be needed to optimize pharmacist resources. Finally, this review was not restricted to Canadian studies, and health care delivery in other countries differs from that in Canada.

\section{CONCLUSION}

A wide variety of patient characteristics, such as older age, polypharmacy, female sex, renal impairment, and decline in cognition, have been associated with ADEs in hospital inpatients. In terms of specific drug classes, anticoagulants, cardiovascular drugs, antibiotics, antihyperglycemic agents, and analgesics have been commonly cited as being associated with ADEs. Prioritization of clinical pharmacy resources according to these risk factors, and further research on interventions aimed at preventing ADEs, could help pharmacists to optimize their impact as members of the patient care team.

\section{References}

1. Sultana J, Cutroneo P, Trifirò G. Clinical and economic burden of adverse drug reactions. J Pharmacol Pharmacother. 2013;4(Suppl 1):S73-7.

2. Baker GR, Norton PG, Flintoft V, Blais R, Brown A, Cox J, et al. The Canadian Adverse Events Study: the incidence of adverse events among hospital patients in Canada. CMAJ. 2004;170(11):1678-86.

3. Glossary of terms used in pharmacovigilance. Uppsala (Sweden): Uppsala Monitoring Centre; 2011 [cited 2015 Dec 28]. Available from: http:// who-umc.org/Graphics/24729.pdf

4. CADTH Information Services. Grey matters: a practical deep-web search tool for evidence-based medicine. Ottawa (ON): Canadian Agency for Drugs and Technology in Health; 2014 [cited 2015 Jul 6]. Available from: https://www.cadth.ca/resources/finding-evidence/grey-matters-practicalsearch-tool-evidence-based-medicine
5. Moher D, Liberati A, Tetzlaff J, Altman DG. Preferred reporting items for systematic reviews and meta-analyses: the PRISMA statement. J Clin Epidemiol. 2009;62(10):1006-12.

6. Alhawassi TM, Krass I, Bajorek BV, Pont LG. A systematic review of the prevalence and risk factors for adverse drug reactions in the elderly in the acute care setting. Clin Interv Aging. 2014;9:2079-86.

7. Petrovic M, van der Cammen T, Onder G. Adverse drug reactions in older people: detection and prevention. Drugs Aging. 2012;29(6):453-62

8. Davies EC, Green CF, Mottram DR, Pirmohamed M. Adverse drug reactions in hospitals: a narrative review. Curr Drug Saf. 2007;2(1):79-87.

9. Krähenbühl-Melcher A, Schlienger R, Lampert M, Haschke M, Drewe J, Krähenbühl S. Drug-related problems in hospitals: a review of the recent literature. Drug Saf. 2007;30(5):379-407.

10. Magro L, Moretti U, Leone R. Epidemiology and characteristics of adverse drug reactions caused by drug-drug interactions. Expert Opin Drug Saf. 2012;11(1):83-94.

11. Kanjanarat P, Winterstein AG, Johns TE, Hatton RC, Gonzalez-Rothi R, Segal R. Nature of preventable adverse drug events in hospitals: a literature review. Am J Health Syst Pharm. 2003;60(17):1750-9.

12. Weiss AJ, Elixhauser A. Healthcare Cost and Utilization Project Statistical Brief 164: Characteristics of adverse drug events originating during the hospital stay, 2011. Rockville (MD): Agency for Healthcare Research and Quality; 2013 [cited 2014 Jun 23]. Available from: www.hcup-us.ahrq.gov/ reports/statbriefs/sb164.pdf

13. Weiss AJ, Elixhauser A, Bae J, Encinosa W. Healthcare Cost and Utilization Project Statistical Brief 158: Origin of adverse drug events in U.S. hospitals, 2011. Rockville (MD): Agency for Healthcare Research and Quality; 2013 [cited 2014 Jun 23]. Available from: www.hcup-us.ahrq.gov/reports/ statbriefs/sb158.pdf

14. National action plan for adverse drug event prevention. Washington (DC): US Department of Health and Human Services, Office of Disease Prevention and Health Promotion; 2014 [cited 2015 Jun 23]. Available from: www.health.gov/hcq/pdfs/ADE-Action-Plan-508c.pdf

15. Wiffen P, Gill M, Edwards J, Moore A. Adverse drug reactions in hospital patients: a systematic review of the prospective and retrospective studies. Bandolier Extra. 2002 Jun [cited 2016 Jul 13]. Available from: www.medicine. ox.ac.uk/bandolier/Extraforbando/ADRPM.pdf

16. Zhu J, Weingart SN. Prevention of adverse drug events in hospitals. In: Post TW, editor. UpToDate [database]. Waltham (MA): UpToDate; [updated 2015 Feb 17; cited 2015 Jun 23]. Accessed through institutional subscription.

Silvija Mihajlovic, BSc, is a PharmD candidate in the School of Pharmacy, University of Waterloo, Kitchener, Ontario.

Jeremie Gauthier, BSCPharm, ACPR, is with The Ottawa Hospital, Ottawa, Ontario.

Erika MacDonald, BScPharm, ACPR, MSc(Epi), is with The Ottawa Hospital and the Ottawa Hospital Research Institute, Ottawa, Ontario.

Competing interests: None declared.

Address correspondence to:

Erika MacDonald

The Ottawa Hospital, Civic Campus

1053 Carling Avenue

Ottawa ON K1H 4E9

e-mail: erimacdonald@toh.ca

Funding: None received. 